
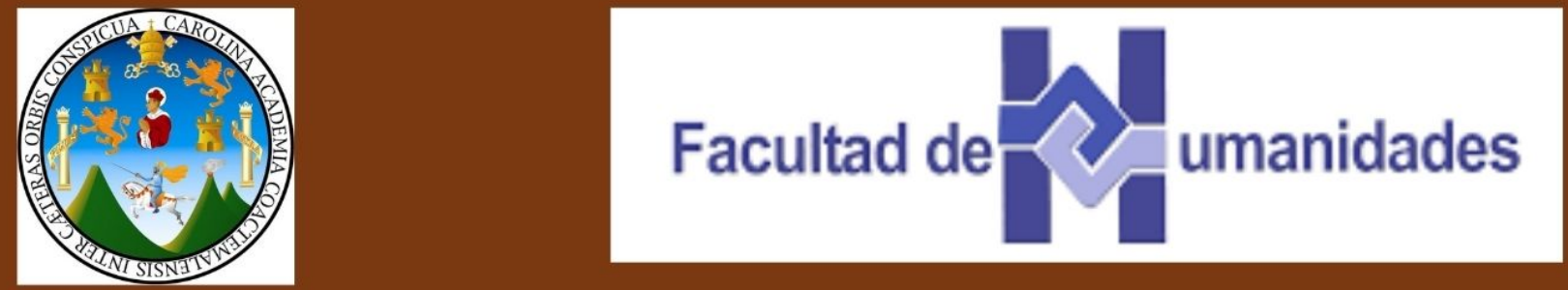

\title{
CONGRESO INTERNACIONAL Nuevas competencias para la edición y difusión de la información
}

\author{
El lenguaje técnico bibliotecario en el contexto de las multialfabetizaciones \\ Herwer Orlando Castillo Valdés \\ Universidad de San Carlos de Guatemala \\ herwercv@yahoo.com
}

Introducción

\section{Materiales y métodos}

La lenguaje técnico dentro del ambito de las Se consultaron articulos alojados en bases multialfabetizaciones, es un elemento fundamental de datos de acceso abierto, y la metodologia de conocer, diferencias y dominar, para que además de difundir los conocimientos, los volvamos nuestros, contribuyendo con ello al desarrollo integral digital de cada indivíduo multialfabetizado. empleada fue la documental, la cual nos permitio obtener los fundamentos teóricos y referenciales de la temática propuesta.

\section{Objetivo}

Motivar a la familiarización del lenguaje técnico relacionado con las multialfabetizaciónes, mejorando con ello la difusión de la información.
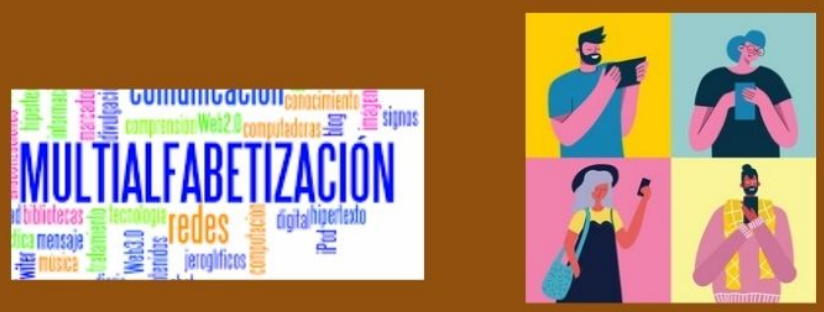

\section{Resultados}

Debido a la era digital en que vivimos, cada día van surgiendo muevas tecnologías digitales, y para obtener el máximo beneficio de las mismas, tanto usuarios como profesionales de la bibliotecología, deben de conocer la extensa terminología, que en relación a las multialfabetizaciones ha surgido, logrando con ello el aprovechamiento tanto de los recursos digitales, como de la información que de ellos se obtenga.

\section{Conclusión}

El surgimiento y reconocimiento de la variedad de multialfabetizaciones existentes, trae consigo, la imperiosa necesidad de conocer y familiarizarse, con el lenguaje técnico, que cada una de las alfabetizaciones nos proporciona, logrando con ello, una mejor compresión, utilización y aplicación de las mismas.

\section{Referencias}

Marzal, M. (2008). Evolución conceptual de la alfabetización en información a partir de la alfabetización múltiple en su perspectiva educativa y bibliotecológica., 23(47), 129-160. http://www.scielo.org.mx/scielo.php?script=sci_arttext\&pid=S0187-358X2009000100006\&lng=es\&tlng=es. 